\title{
Fecundity, survival, and growth of the seahorse Hippocampus ingens (Pisces: Syngnathidae) under semi-controlled conditions
}

\author{
A.A. Ortega-Salas ${ }^{1} \&$ H. Reyes-Bustamante ${ }^{2}$ \\ 1 Instituto de Ciencias del Mar y Limnología, UNAM. Calz. Joel M. Camarena s/n, Mazatlán 82040, Sinaloa Apdo. \\ Post. 811; ortsal@mar.icmyl.unam.mx \\ 2 Facultad de Ciencias del Mar, Universidad Autónoma de Sinaloa, Sinaloa, México
}

Received 24-II-2006. Corrected 27-III-2006. Accepted 11-VIII-2006.

\begin{abstract}
We studied fecundity, survival, and growth of the seahorse Hippocampus ingens under semi-controlled conditions. Three wild brood stock mature males of 14.8, 24.5, and 32.0 g released 1598,1703 , and 1 658 juveniles. Juvenile stocking densities of 12 were settled in 60-1 aquariums in groups of 1, 12, and 20 days old organisms. The rate of survival was $21.5,61.9$, and $59.0 \%$, respectively, in 35 days. Juveniles were fed a mix diet of rotifers B. plicatilis and Artemia nauplii, then they were transferred to a cement tank of 1000001 at a density of 50/1 0001 and fed with live adult Artemia for 60 days more. They grew from an average of 0.7 , 1.5 , and 2.7 to $4.5,5.4$, and $6.7 \mathrm{~cm}$, respectively, in 95 days. The seawater temperature varied from 17 to $23{ }^{\circ} \mathrm{C}$. Rev. Biol. Trop. 54 (4): 1099-1102. Epub 2006 Dec. 15.
\end{abstract}

Key words: seahorse, Hippocampus ingens, aquaculture, growth, mortality.

Several species of Hippocampus have been commercially exploited for several years without proper knowledge of culture techniques. Seahorses have been mainly caught in China, Thailand, India, and the Philippines for many years (Mi 1992). Commercial demands for seahorses, mainly for medical purposes, are increasing by $20 \%$ per year and the price per kilogram of dried seahorse varies from US\$ 400.00 to 1300.00 (Vincent 1994).

Liang (1992) studied $H$. ramalassus reproduction and assured that artificial production would allow the preservation of this Hippocampus species. The aim of this paper was to count and calculate fecundity, survival, and growth of the seahorse Hippocampus ingens under semi-controlled conditions.

\section{MATERIALS AND METHODS}

Three wild brood stock mature male were used in this study. They were weighed just before they released the juveniles, and after they released them to estimate the total weight. The average individual weight was estimated dividing the total larval weight by the number of juveniles released. All the released juveniles per each mature male were counted; the relative fecundity was calculated dividing the number of juveniles per gram of seahorse body weight before release of the juveniles. After 35 days the juveniles were counted to calculate mortality.

Three groups of juveniles aged 1, 12, and 20 days old were used (60 organisms each) to calculate growth every 15 days for the 95 daysduration of this study (Fig. 2). The length (mm) and weight (g) parameters from the three groups of released juveniles were used to calculate growth by the least square method to estimate changes in length and weight with time.

The seahorse juveniles at a stocking density of 12 were settled in 601 aquariums in groups of 1,8 , and 20 days old organisms with a mixture of microalgae culture of Chaetoceros and Tetracelmis between 500000 
and 100000 cells $/ \mathrm{ml}$; they were fed at a density rate of 75 rotifers $/ \mathrm{ml}$, and Artemia nauplii at a density of 1 to $2 / \mathrm{ml}$ for 35 days. Then they were transfer to a cement tank of $100000 \mathrm{l}$ at a density of 50/1 0001 and fed with live Artemia adult at a rate of $2 / \mathrm{ml}$ for 60 days more. The seawater temperature registered in this study varied from 17 to $23{ }^{\circ} \mathrm{C}$.

\section{RESULTS}

Figure 1 shows the length-weight relationship of 9 males and 10 females caught at random in the sea.

The equations show that for a given length males are heavier. Average length of males was $16.6 \mathrm{~cm}( \pm 2.83 \mathrm{SD})$. Average length of females was $15.3 \mathrm{~cm}( \pm 3.21 \mathrm{SD})$. A t-test and mean differences revealed a significant difference between sexes according to the mean length

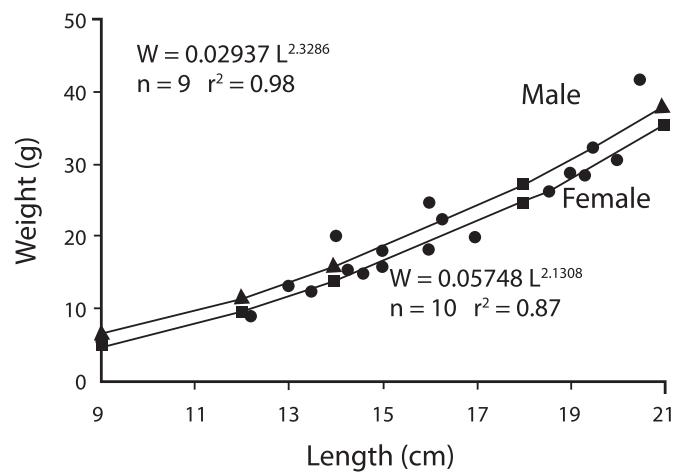

Fig. 1. Length-weight relationship of mature seahorses at random caught in the sea.

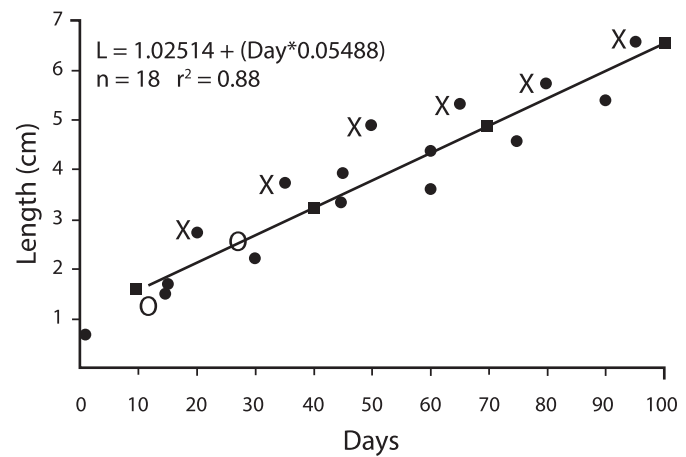

with $6.01 ; 95 \%$ confidence interval; d.f. $=17$; $\mathrm{t}=-1.51$; significance level $=0.34$, even with mean weight there were significant differences between sexes with $-1.3 ; 95 \%$; d.f. $=17$; $\mathrm{t}=$ 096; significance level $=0.14$, at $\mathrm{p}<.05$.

Three mature males released 1 598, 1 703, and 1658 juveniles giving a total of 4959 juveniles in 20 days, which gave an averageweight male of $23.7 \mathrm{~g}$, a larval release of 1653 , and a relative fecundity of 76.43 juveniles per gram of seahorse (Table 1). Survival registered for 1598,1703 and 1658 released juveniles was 343, 1054 and 978 juveniles, respectively, which means $78.5,38.1$ and $41.0 \%$ survival rates, respectively.

Figure 2 shows the increase of the average length and weight from the three groups of juveniles, every 15 days. The equations indicate that the average length and growth rate from the three groups were $0.05 \mathrm{~cm}$ and $0.005 \mathrm{~g}$ per unit of time (days), respectively.

Figure 3 shows the average growth in length and weight of juveniles from the three groups, from which a length-weight relationship was calculated; starting with the $3 \mathrm{~cm}$ length, weights increased geometrically.

Sexual differences in juveniles were observed at 95 days of age at a length range between 6 and $7 \mathrm{~cm}$.

\section{DISCUSSION}

The temperature of the seawater reported in this paper ranged between 17 to $23{ }^{\circ} \mathrm{C}$,

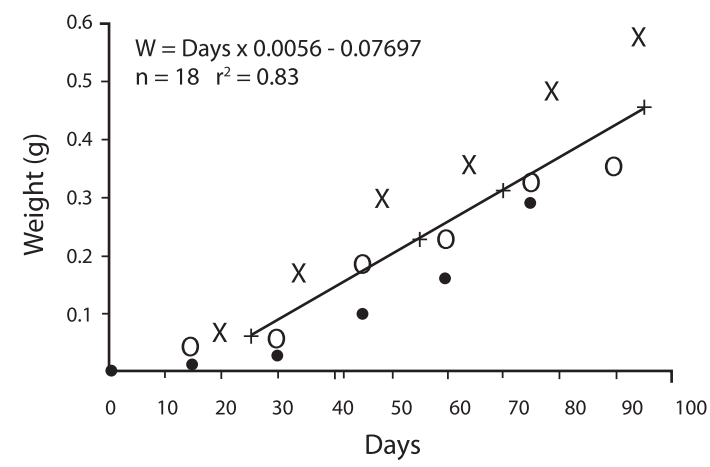

Fig. 2. Growth in length and weight of juvenile seahorses. $(1,8$, and 20 days old) group $1(\bullet)$, group $2(\mathrm{O})$, and group 3 $(\mathrm{X})$, respectively. 
TABLE 1

Three ripe males weighed before and after releasing juveniles, number of juveniles released, the relative fecundity (released juveniles/fish weighed before), and survival rates

$\begin{array}{ccccccc}\text { Date } & \begin{array}{c}\text { Weight } \mathrm{g} \\ \text { (before) }\end{array} & \begin{array}{c}\text { Weight g } \\ \text { (after) }\end{array} & \begin{array}{c}\text { Released } \\ \text { (juveniles) }\end{array} & \begin{array}{c}\text { Relative } \\ \text { Fecundity }\end{array} & \text { Survival juveniles } & \text { Survival } \\ \text { 19/11/1998 } & 14.8 & 13.7 & 1598 & 107.97 & 343 & 21.5 \\ 01 / 12 / 1998 & 24.5 & 23.3 & 1703 & 69.51 & 1054 & 61.9 \\ 08 / 12 / 1998 & 32 & 30.8 & 1658 & 51.81 & 978 & 59 \\ \text { Average } & 23.767 & 22.6 & 1653 & 76.43 & 791.67 & 47.467\end{array}$

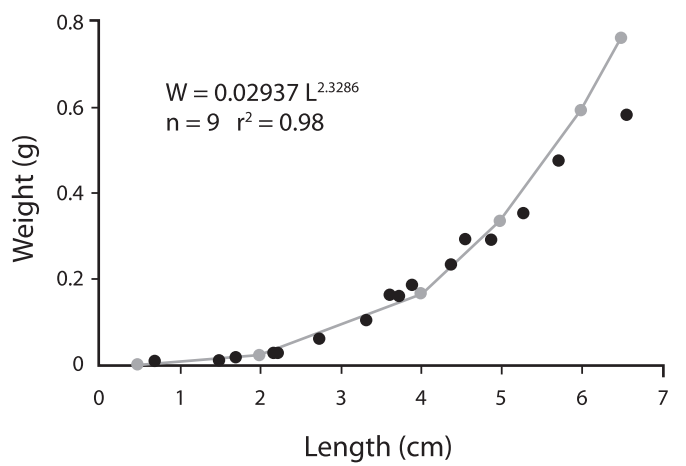

Fig. 3. Length-weight relationship of juvenile seahorses.

although Tawil (1994) reported temperatures for this species from 3 to $27^{\circ} \mathrm{C}$. In other species Vincent and Clifton (1989) found an optimal temperature of $27^{\circ} \mathrm{C}$ for $\mathrm{H}$. erectus, and Fam (1992) reported an optimal temperature of $21{ }^{\circ} \mathrm{C}$ for $H$. kuda.

In this work three mature males of 14.8 , 24.5 and $32.0 \mathrm{~g}$ released 1 598, 1 703, and 1658 juveniles, respectively, which is not very different from the results obtained by Reyes-Bustamante and Ortega-Salas (1999) who reported that four ripe males with a length between 18.9 to $20.3 \mathrm{~cm}$ and weighting between 25.1 to 26.5 g. released $1200,1450,1600$, and 1600 juveniles in five days, giving an average of 1462 juveniles per male; although Tawil (1994) mentioned that $H$. ingens could release up to 6000 juveniles from heavier ripe males. In other species, Axelrod et al. (1969) found a release from 150 to 600 juveniles by $H$. guttatus; Pivnicka and Cemy (1991) reported between 100 to 200 juveniles in $H$. ramalassus; $\mathrm{Mi}$ (1993) estimated between 20 to 1000 juveniles in H. kuda after 20-28 days in the brood pouch; and Vincent (1994) reported between 1572 to 1 753 juveniles in $H$. hippocampus.

Vincent (1994) calculated an average length at hatching of $0.9 \mathrm{~cm}$ for $H$. ingens; Graff (1968) estimated $2.5 \mathrm{~cm}$ in H. enano; Karel and Karel (1991) found $2.52 \mathrm{~cm}$ in $H$. gluttatus; Minelli (1985) reported a length of $0.3 \mathrm{~cm}$ in $H$. hippocampus, and Fam (1992) calculated $1 \mathrm{~cm}$ for $H$. kuda. This study showed that $H$. ingens juveniles were hatched with a length of 0.7 and reach $1.5 \mathrm{~cm}$ the first week, and $2.18 \mathrm{~cm}$ in one month; they were fed with rotifers. Under similar conditions, Reyes-Bustamante and OrtegaSalas (1999) calculated a better growth from an initial length of $0.69 \mathrm{~cm}$ to reach $2.84 \mathrm{~cm}$ in one month; they were fed with a variety of live food such as rotifers, copepods, and Artemia nauplii. In H. erectus, Correa et al. (1989) registered $1.3 \mathrm{~cm}$ of initial length that grew to $3.47 \mathrm{~cm}$ in 35 days; they were fed with Artemia nauplii. Liang (1992) mentioned that $H$. japonicus is larger than $4.5 \mathrm{~cm}$ after one month. Tawil (1994) estimated that $H$. ingens reached $3.5 \mathrm{~cm}$ in one month.

As observed $H$. ingens and $H$. kuda are the largest species reaching a $30 \mathrm{~cm}$ length but hatching smaller juveniles as compared with the other species that are smaller in adult length but hatch bigger juveniles, such as $H$. enano. Reyes-Bustamante and Ortega-Salas (1999) calculated from the length-weight relationship of juveniles, a slope of 2.98 , which compared with the 3.09 slope obtained in this study, indicates a slightly heavier body weight for a given length. 
In this study, mortality was $38.1,41.0$, and $78.5 \%$ in 95 days (Table 1). Reyes-Bustamante and Ortega-Salas (1999) calculated a mortality rate between 20 to $40 \%$ in 63 days; juveniles were fed with live food in both cases. In other species Fam (1992) and Liang (1992) mentioned for Hippocampus kuda that food supply such as fresh and live copepods at the fry stage is good for growth promotion, disease resistance, and survival. Correa et al. (1989) calculated a mortality of $50.67 \%$ for $H$. erectus in 35 days; however if water and quality food improved, survival rate increased to $97.08 \%$ for juveniles and $70 \%$ for adults.

The success of rearing at least $50 \%$ of the seahorse juveniles to young commercial stages at temperatures between 17 and $23{ }^{\circ} \mathrm{C}$ was due to the good quality and quantity of live food under appropriate seawater conditions in the laboratory and using open-air tanks.

\section{ACKNOWLEDGMENTS}

We thank A. Nuñez P, J.L. Beltrán M., J.A. Ortega R. and C. Ramírez for their devoted participation in this study.

\section{RESUMEN}

Estudiamos la fecundidad, supervivencia, y crecimiento del caballito de mar, Hippocampus ingens en condiciones semi-controladas. Tres machos reproductores silvestres de 14.8, 24.5 y 32.0 g produjeron 1598,1703 y 1658 jóvenes. La densidad utilizada fue de 12 jóvenes por acuario de 601 . Se agruparon en 1, 12 y 20 días de nacidos por acuario. La supervivencia fue de $78.5,38.1$ y $41.0 \%$ en 35 días. Se les alimentó con una mezcla de rotíferos B. plicatilis y nauplios de Artemia para después transferirlos a estanques de 1000001 a una densidad de 50/1 0001 , donde se les alimentó con Artemia adulta durante 60 días más. Crecieron de un promedio de $0.7,1.5$, y 2.7 a $4.5,5.4$ y $6.7 \mathrm{~cm}$, respectivamente, en 95 días. La temperatura del agua marina utilizada varió de 17 a $23{ }^{\circ} \mathrm{C}$.
Palabras clave: caballito de mar, Hippocampus ingens, acuicultura, crecimiento, mortalidad.

\section{REFERENCES}

Axelrod, H., W. Burges \& C. Emmens. 1969. Exotic marine fishes. TFH, New York, USA. p. 400-409.

Correa, M., K.S. Chung \& R. Manrique. 1989. Experimental culture of the seahorse, Hippocampus erectus. Bol. Inst. Oceanog. de Venezuela 28: 91-196.

Fam, T.M. 1992. Rearing of the seahorse Hippocampus kuda. Biol. Morya Mar. Biol. 56: 93-96.

Graff, F. 1968. Marine Aquarium Guide. Pet Library, London, England. 184-187 p.

Karel, P. \& C. Karel 1991. Caballito de Mar Hippocampus guttatus. El Gran Libro de los Peces. Susaeta, Madrid, Spain. $176 \mathrm{p}$.

Liang, B. 1992. Research on the culture of Hippocampus. J. Oceanol. Univ. Qingdao Peopl. Rep. China 22: 39-44.

Mi, P.T. 1992. Raising the sea horse Hippocampus kuda. Russ. Jour. Mar. Biol. 18: 93-96.

Mi, P.T. 1993. Raising the sea horse Hippocampus kuda. Biol. Mor. 18: 203-205.

Minelli, A. 1985. Nueva enciclopedia del reino animal. Inst. Biól. Anim., Universidad de Padua, Padua, Italy. $180 \mathrm{p}$.

Pivnicka, K \& K. Cemy. 1991. Caballito de mar, Hippocampus guttulatus. El gran libro de los peces. SUSAETA, Madrid, Spain. 304 p.

Reyes-Bustamante, H. \& A.A.Ortega-Salas. 1999. Cultivo del caballito de mar, Hippocampus ingens (Pisces: Syngnathidae) (Girard, 1859) en condiciones artificiales. Rev. Biol. Trop. 47: 1045-1049.

Tawil, G.A. 1994. Aqua Guía Méx. 2: 28-33.

Vincent, A. 1994. The improbable Sea horse. Natl. Geogr. 186: 126-140.

Vincent, A.C.J. \& H.R.S. Clifton. 1989. Parasitic infection of the sea horse Hippocampus ingens a case report. J. Wild Dis. 25: 404-406. 